Summer 2007

\title{
International Commerce and Undocumented Workers: Using Trade to Secure Labor Rights
}

Laura Jakubowski

Indiana University School of Law

Follow this and additional works at: https://www.repository.law.indiana.edu/ijgls

Part of the Commercial Law Commons, Immigration Law Commons, International Law Commons, and the Labor and Employment Law Commons

\section{Recommended Citation}

Jakubowski, Laura (2007) "International Commerce and Undocumented Workers: Using Trade to Secure Labor Rights," Indiana Journal of Global Legal Studies: Vol. 14 : Iss. 2 , Article 14.

Available at: https://www.repository.law.indiana.edu/ijgls/vol14/iss2/14

This Note is brought to you for free and open access by the Law School Journals at Digital Repository @ Maurer Law. It has been accepted for inclusion in Indiana Journal of Global Legal Studies by an authorized editor of Digital Repository@Maurer Law. For more information, please contactrvaughan@indiana.edu.

\section{$\Psi$}

JEROME HALL LAW LIBRARY

INDIANA UNIVERSITY

Maurer School of Law
Bloomington 


\title{
International Commerce and Undocumented Workers: Using Trade to Secure Labor Rights
}

\author{
LaURa JaKuBowsKi
}

Abstract

This article explores the rights of illegal immigrants and undocumented workers throughout the world. International treaties have attempted to deal with the rights of undocumented workers, but few countries have been willing to sign on to the treaties. This article argues that undocumented workers should have more expansive rights, and that international trade agreements and institutions should be used where human rights and domestic solutions have failed to guarantee the rights of the most vulnerable workers.

\section{INTRODUCTION}

Chinese workers in the United Kingdom drown in Morecombe Bay while working as cockle pickers. ${ }^{1}$ Female migrants suffering on-the-job brain damage are summarily deported from South Korea without receiving medical treatment. ${ }^{2}$ In the United States, workers who contributed to Social Security and are now permanent residents may be barred from taking Social Security credits when they are eligible, ${ }^{3}$ and the border with Mexico is militarized for the sole purpose of keeping out undocumented immigrants. ${ }^{4}$ In Spain, a country which just twenty

J.D., 2007, Indiana University School of Law, Bloomington. I would like to thank Kenneth G. Dau-Schmidt, Willard and Margaret Carr Professor of Labor and Employment Law at the Indiana University School of Law, Bloomington, for his helpful guidance and comments.

1. Hsiao-Hung Pai, Film to Focus on Chinese Migrants, The Guardian, Oct. 30, 2004, at 9.

2. Activists, Workers Call to End Crackdown on Migrant Workers, Yon a a, Feb. 27, 2005.

3. Bill Would Ban Social Security Credits for Immigrants Who Worked Illegally, Сн. TRIB., Aug. $31,2004, \S 3$, at 3 .

4. On May 15, 2006, President George Bush announced the deployment of 6,000 National Guard troops to the U.S.-Mexico border in order to provide "temporary logistical and administrative support to U.S. Border Patrol agents." Geri Smith, Bush Plan Provokes Mexico's Ire, Bus. WK. ONLINE, May 17, 2006, http://www.businessweek.com/globalbiz/content/may2006/ 
years ago experienced large-scale emigration of its citizens to other European countries, irregular immigration from Africa has become the most contentious political issue of the day, ${ }^{5}$ as hundreds of undocumented immigrants arrive daily in makeshift boats to the Canary Islands. ${ }^{6}$

These facts are important because they demonstrate both the disturbing treatment that undocumented workers often receive in their countries of employment and also the continued increase and changing trends in cross-border migration. In recent years, irregular immigration and the exploitation of migrant workers in their countries of employment have made headlines and captured the attention of the international community. After demonstrations in cities across the United States in the spring of 2006 supporting the rights of undocumented

gb20060517_978687.htm? chan=search. This announcement provoked concern from Mexican academics and politicians that the militarization of the border would lead to human rights abuses and damage economic relations between the United States and Mexico. Id. There is a great deal at stake, considering the volume of bilateral trade between the two countries-approximately $\$ 290$ billion in 2005. Id. Although detentions along the border have decreased since the National Guard deployment, it is not clear how much of this decrease is a result of greater patrol presence, as factors such as harsh weather and increasing smugglers' fees also affect the number of irregular border crossings. Olga R. Rodriguez, National Guard Troops Scaring Away Migrants, S. Fla. Sun-SentıNEL, June 13, 2006, at A2.

5. Increased migration to Spain from Africa and the Spanish government's legalization of approximately 500,000 undocumented workers last year has drawn criticism both nationally and from other EU countries. See, e.g., Chirac recrimina de nuevo a Zapatero la regularización extraordinaria de inmigrantes, LA VANGUARDIA, Oct. 20, 2006, http://www.lavanguardia.es/ gen/20061020/51288677898/noticias/chirac-recrimina-de-nuevo-a-zapatero-la-regularizacion-extraordinaria-de-inmigrantes-schengen-jose-luis-rodriguez-zapatero-jacques-chirac-finlandia. html; Zaplana critica al Gobierno por pretender "esconder" el problema de la inmigración con una subcomisión, LA VANGUARDia, Oct. 11, 2006, http://www.lavanguardia.es/gen/20061011/ 51287279343/noticias/zaplana-critica-al-gobierno-por-pretender-esconder-el-problema-de-lainmigracion-con-una-subcomision-pp-maria-teresa-fernandez-inmigracion-congreso.html; Rajoy ofrece a Zapatero su programa en inmigración para que deje de "improvisar" y de dar "palos de ciego", LA VANGUardia, Oct. 8, 2006, http://www.lavanguardia.es/gen/20061008/51286522228/noticias/ rajoy-ofrece-a-zapatero-su-programa-en-inmigracion-para-que-deje-de-improvisar-y-de-darpalos-de-ciego-pp-rodriguez-zapatero-parlamento-europeo-opa.html.

6. See, e.g., Arriba un cayuco con 139 inmigrantes al sur de Tenerife, La Vanguardia, Oct. 14, 2006, http://www.lavanguardia.es/gen/20061014/51287683510/noticias/arriba-un-cayuco-con-139-inmigrantes-al-sur-de-tenerife-guardia-civil-cruz-roja.html; Otros 40 inmigrantes irregulares fueron detenidos tras llegar a las costas tinerfeñas, LA VANGUARDiA, Oct. 19, 2006, http://www.lavanguardia.es/ gen/20061019/51288481265/noticias/otros-40-inmigrantes-irregulares-fueron-detenidos-tras-llegara-las-costas-tinerfenyas-tenerife-gran-canaria-canarias.html; Detenidos otros 36 inmigrantes tras arribar a bordo de una patera a Fuerteventura, LA VANGUaRdia, Oct. 21, 2006, http://www.lavanguardia. es/ gen/20061021/51288781399/noticias/detenidos-otros-36-inmigrantes-tras-arribar-a-bordo-de-unapatera-a-fuerteventura-rosario-guardia-civil-tenerife-sistema-integral-cruz-roja.html. 
migrants, it seemed that a previously silent group may finally have found a voice. Yet despite all the recent attention, undocumented workers $^{8}$ remain a highly vulnerable social group in most receiving countries, and the law has done little to protect them. Receiving countries generally still fail to respond with comprehensive and fair solutions to the problems posed by irregular migration. ${ }^{9}$

Taking into account the social sensitivity, depth, and intricacy of the phenomenon of migration as a whole, it is hardly surprising that individual states have failed in their responses. At a time when the idea of universal human rights has been firmly accepted, at least in principle, by almost all states, the application of human rights to irregular migrants has been unsuccessful. Because control over immigration is characterized as essential to a nation's sovereignty, conceding rights to those who threaten sovereignty by entering a country without permission poses a unique challenge..$^{10}$ Most states are unwilling to protect undocumented workers in practice and are even unwilling to acknowledge that such an obligation to protect exists. Despite their lack of protection and susceptibility to abuse, however, workers across the world continue to migrate in search of em-

7. See, e.g., Randal C. Archibold, Immigrants Take to U.S. Streets in Show of Strength: Planned Boycott Evolves into Protests, N.Y. Times, May 2, 2006, at A1; Nina Bernstein, In the Streets, Suddenly, an Immigrant Groundswell, N.Y. TimEs, Mar. 27, 2006, at A14; Michelle O'Donnell, Thousands Turn Out, But Support Is Mixed Among City's Immigrants, N.Y. TIMEs, May 2, 2006, at Al8.

8. In U.S. immigration law, the term "undocumented" is often used to refer to those who are living or working in the United States without permission from the Citizenship and Immigration Services. This group includes both those who entered the country without permission and those who entered with valid visas and stayed beyond the authorized time period. See Jorge A. Vargas, U.S. Border Patrol Abuses, Undocumented Mexican Workers, and International Human Rights, 2 SAn Diego INT'L L.J. 1, 21-22 (2001). In international law, the term "irregular migrant" is used to refer to those who are living without permission in countries other than their countries of origin. See, e.g., Kenneth Christie, Book Review: Irregular Migration and Human Rights: Theoretical, Eurpean, and International Perspectives, 18 J. Refugen STud. 127 (2005). This article uses the terms "undocumented worker," "undocumented migrant," and "irregular migrant" interchangeably, to refer to those who are living and working without authorization in a country other than their home country-both those who entered clandestinely and those who entered with a visa and stayed beyond their authorized time period.

9. For example, the U.S. Executive responded to increasing concern over irregular migration by deploying National Guard troops to the U.S. border with Mexico. Smith, supra note 4. In Spain, the decision to legalize undocumented foreign workers was made without consulting other Schengen or EU countries, leading to unwillingness on the part of others to help with the problem Spain is currently facing. Chirac recrimina de nuevo a Zapatero la regularización extraordinaria de inmigrantes, supra note 6.

10. See, e.g., Chae Chan Ping v. United States, 130 U.S. 581, 603 (1889) ("That the government ... can exclude aliens from its territory is a proposition which we do not think open to controversy. Jurisdiction over its own territory to that extent is an incident of every independent nation."). 
ployment opportunities. Regional integration and interdependence further facilitate migration, while at the same time making it more contentious.

It is time to recognize the inadequacy of human rights instruments to protect these workers and move toward a different, more interest-based framework to regulate irregular migration and defend the rights of individual workers. Migrant-sending states have to put pressure on migrant-receiving states to recognize the importance of cross-border movement of unskilled labor through advocating for protection of irregular migrants' labor rights, regularization of immigration status for undocumented workers, and decreased restrictions on movement of needed laborers. Sending states and advocacy groups that represent irregular migrants should consider the role of trade instruments and institutions in advocating for these workers' rights. Although it is a noble goal to work for the protection of all workers' rights through an enduring and universal human rights instrument, a necessary first step is to tie workers' rights directly to national economic well-being, offering unmistakable incentives to give undocumented workers the basic respect that they deserve.

\section{The Scope Of International Migration}

Worldwide, over 175 million people are international migrants." Of this number, approximately 81 million are migrant workers, and 10 to 15 percent are irregular migrants. ${ }^{12}$ According to estimates of the International Labor Organization, there are approximately 47 million migrants in the Americas, with between 8 and 11 million in the United States alone. ${ }^{13}$ Europe is host to the greatest number of migrant workers on a single continent, followed by Asia. ${ }^{14}$ As international economic development continues to change the labor market, leaving many at the margins, these numbers are likely to increase. ${ }^{15}$ Despite tighter immigration controls and stronger security measures in many countries, the number of migrant workers, especially in Europe and North America, continues to grow. The "fault line[s] between haves and have-nots," such as the Strait of Gibraltar between Spain and Morocco and the

11. Sandesh Sivakumaran, The Rights of Migrant Workers One Year On: Transformation or Consolidation?, 36 Geo. J. InT'L L. 113, 113 (2004).

12. Sarah Paoletti, Human Rights for All Workers: The Emergence of Protections for Unauthorized Workers in the Inter-American Human Rights System, Huм. RTs. BRIEF, Fall 2004, at 5.

13. Id.

14. Id.

15. Luis de Sebastián, Algunas Sorpresas de la Globalización 3-6 (Sept. 25, 2006) (unpublished manuscript, on file with author). 
Rio Grande on the United States' southern border, have been characterized as “indefensible." Irregular migration is not a problem that can be solved with increased security, as it is a phenomenon that is almost entirely about the demand for labor. ${ }^{17}$ As long as this demand exists, workers will continue to leave their home countries and find ways to reach the employers that are in need of their labor.

The sheer number of migrants and migrant workers worldwide is overwhelming. In the United States, this is something that has come into clear relief as a result of demonstrations in cities across the country demanding rights for all immigrants, especially the undocumented. ${ }^{18}$ Despite the power that lies in numbers, however, for reasons ranging from voter ineligibility, domestic backlash over liberal immigration policies, and failure of immigrant communities to organize as a result of language barriers and individuals' fear of deportation, migrant workers rarely have a strong political voice in their countries of employment. This is especially true of irregular migrants, who have a powerful incentive to maintain as low a profile as possible, above all in relation to employment. ${ }^{19}$ The vulnerability of undocumented workers makes them easy targets for a multitude of human rights violations at the hands of their employers. ${ }^{20}$ These abuses include low and unpaid wages, exclusion from unions, and dangerous or unhealthy work conditions. ${ }^{21}$ For female migrants, the abuses may be even more severe, as between one and two million women are trafficked each year for purposes of forced labor, marriage, and prostitution. ${ }^{22}$ Many more women migrate voluntarily and end up

16. Leslie Crawford, Migrant Workers Obeying the Cold Laws of Economics, Fin. TImes (London), Jan. 19, 2001, http://specials.ft.com/europereinventedl/FT3MXGTIWHC.html.

17. Id.

18. See Archibold, supra note 7.

19. See John W. Budd, Employment with a Human Face: Balancing Efficiency, Equity, and Vorce 150-51 (2004). For undocumented workers, the possibility of deportation provides a strong disincentive to report abusive labor practices. Despite this, there have been prominent examples, above all in the United States, of successful organization of undocumented immigrant workers to demand rights. Id. Aside from recent political demonstrations, the United Farm Workers under the leadership of Cesar Chavez in the 1960s, and the Justice for Janitors campaign in Los Angeles in the 1990s are the most well-known examples. Id. However, although these movements at least brought attention to the situation of immigrant workers, they brought negative political backlash and lost momentum with the overall decrease in the power of labor unions in the United States.

20. Paoletti, supra note 12 , at 6.

21. See Alan A. Stevens, Give Me Your Tired, Your Poor, Your Destitute Laborers Ready to Be Exploited: The Failure of International Human Rights Law to Protect the Rights of Illegal Aliens in American Jurisprudence, 14 EMory INT'L L. Rev. 405, 433-35 (2000).

22. Shelley Case Inglis, Expanding International and National Protections Against Trafficking for Forced Labor Using a Human Rights Framework, 7 Buff. Hum. RTs. L. Rev. 55,55 (2001). 
in conditions of slave labor. In the United States alone, there are an estimated 16,000 cases of slavery each year. ${ }^{23}$ Most of these cases begin as human smuggling from Mexico and result in the undocumented migrants being held in captivity and used as slaves. ${ }^{24}$ Particular problems in human smuggling also exist between Ukraine and Germany, Burma and Thailand, Russia and Israel, and the Philippines and Kuwait. ${ }^{25}$ The United Nations Special Rapporteur on Violence Against Women has reported that many trafficked women do not report their traffickers for fear of reprisals, legal sanctions, and arrest. ${ }^{26}$

This disincentive for reporting abuse exists not only for victims of trafficking, but for all irregular migrants who are victims of abuse by their employers. Most undocumented workers have much to lose and little to gain from reporting substandard working conditions and wages or even more serious forms of physical violence such as physical or sexual assault. In the past few years, this has become a particular problem in the United States. In 2002, the U.S. Supreme Court made a decision to withhold back pay from an undocumented worker who was illegally fired for participation in a union. ${ }^{27}$ The Court's denial of a meaningful remedy to undocumented workers whose rights are violated has led to a sharp increase in the number of employers who threaten to have workers deported if they pursue claims. ${ }^{28}$

\section{Human Rights Solutions}

The problems faced by irregular migrants have been recognized by the international community and have prompted response from the United Nations and the International Labor Organization (ILO). Both the United Nations and ILO have issued declarations and promulgated human rights accords that encompass all individuals, including irregular migrants. The U.N. International Convention on Civil and Political Rights (ICCPR) and the International Convention on Social, Cultural and Economic Rights (ICESCR) guarantee basic human rights to all persons, with-

23. Migrant Traffickers Force Undocumented Migrants into Slavery in the U.S., El UNIVERSAL (Mexico), May 3, 2005.

24. Id.

25. Inglis, supra note 22.

26. Id. at $81-82$.

27. Hoffman Plastic Compounds, Inc. v. NLRB, 535 U.S. 137, 140 (2002).

28. Sarah Cleveland, Beth Lyon \& Rebecca Smith, Inter-American Court of Human Rights Amicus Curiae Brief: The United States Violates International Law When Labor Law Remedies Are Restricted Based on Workers' Migrant Status, 1 Seatrle J. Soc. Just. 795, 870 (2003). 
out any sort of distinction. ${ }^{29}$ The United Nations specifically addressed the rights of migrants in the Declaration on the human rights of individuals who are not nationals of the country in which they live. ${ }^{30}$ Likewise, the ILO Declaration on Fundamental Principles and Rights at Work, binding on all Member States of the ILO, guarantees rights to freedom of association, collective bargaining, and the elimination of discrimination, without any exception. ${ }^{31}$ Both the ICESCR and the ICCPR have been ratified by developed countries that host a large population of undocumented immigrants, including the United States and most of Europe and Asia.

In practice, however, the ICESCR, the ICCPR, and the United Nations' and ILO Declarations have not had significant benefits for undocumented workers. None of the instruments explicitly mentions the significant world population of irregular migrants or recognizes the incentive that these individuals have to hide violations of their rights in order to avoid deportation. Further, the ICCPR and ICESCR allow discrimination against aliens when such discrimination is "objective and reasonable." ${ }^{32}$ In order to recognize unequivocally the rights of both documented and undocumented migrant workers, the U.N. General Assembly drafted the Convention on the Protection of the Rights of All Migrant Workers and Members of Their Families (Migrant Workers Convention). ${ }^{33}$ This treaty is the first U.N. instrument to provide explicit protection for the rights of undocumented migrant workers. The instrument was opened for signature in 1991 and was immediately signed and ratified by Mexico and Morocco. ${ }^{34}$ Despite the participation of a great number of countries in the drafting process, the Convention was not ratified by the required number of nations to enter into force until $2003 .{ }^{35}$ The Migrant Workers Convention recognizes that the exploitability of undocumented workers often makes them attractive to employers, therefore fueling ille-

29. International Covenant on Civil and Political Rights, Dec. 16, 1966, 999 U.N.T.S. 171, 6 I.L.M. 368; International Covenant on Economic, Social and Cultural Rights, Dec. 16, 1966, 993 U.N.T.S. 3, 6 I.L.M. 360.

30. Declaration on the human rights of individuals who are not nationals of the country in which they live, G.A. Res. 40/144, U.N. GAOR, 40th Sess., 116th plen. mtg. (Dec. 13, 1985).

31. International Labor Organization, ILO Decalartion on Fundamental Principles and Rights at Work, Geneva, June 1998, available at http://www.itcilo.it/actrav/declaration/common/declaration_ txt.html; Lee Swepston, Introductory Note, International Labour Conference: ILO Declaration on Fundamental Principles and Rights at Work, 37 I.L.M. 1233, 1233-34 (1998).

32. Stevens, supra note 21 , at 413.

33. International Convention on the Protection of the Rights of All Migrant Workers and Members of Their Families, G.A. Res. 45/158, Annex, U.N. Doc. A/RES/45/158/Annex (Dec. 18, 1990) [hereinafter Migrant Workers Convention].

34. Id.

35. Id. 
gal immigration in spite of border patrol or other law enforcement efforts. The Convention also urges that preventing exploitation of undocumented migrants will discourage clandestine immigration by making undocumented workers less advantageous for employers to hire. ${ }^{36}$

The Convention separately addresses rights that are guaranteed to all migrant workers irrespective of immigration status and rights that are guaranteed only to legal migrants. Part IV of the Convention enumerates the rights of legal migrants, and Part III addresses those rights that are guaranteed to both regular and irregular migrants. The rights enumerated in Part III cover a broad range of issues, leading to apprehension in many countries regarding ratification of the instrument. Rights explicitly provided for irregular migrant workers on the job include protection from violence and equal employment conditions with other workers. Equality of employment conditions includes equal pay for equal work, overtime pay, holidays, safety and health on the job, and the right to join and participate in trade unions. ${ }^{37}$ All these rights are guaranteed directly against the employer by the terms of the Convention. In addition, irregular migrant workers are afforded fundamental rights against the country in which they reside, including the right to emergency medical care, the right to education for their children, respect for cultural identity, and procedural safeguards on expulsion from their country of residence. These procedural safeguards include individual and competent consideration of the case, notification of the reasons for removal (in the migrant's native language), and the opportunity to appeal and request a stay of an order of deportation. ${ }^{38}$ Although the Convention does not include an obligation to legalize undocumented workers who are already present in a state's territory, it does recognize that regularization of status is important, urging states to consider factors such as family situation and duration of stay if the decision is made to offer a legalization program. In addition, ILO Convention No. 143 urges states to make decisions quickly regarding legalization of undocumented individuals. ${ }^{39}$

The Migrant Workers Convention's inclusion of irregular migrants is symbolically significant, as it demonstrates how human rights transcend state sovereignty. ${ }^{40}$ Many of the previously noted abuses of irregular migrants--inhumane mass expulsions and deportations in Malaysia and Morocco, denial of medical treatment in

36. Id. at 1523 .

37. Id. at 1525-34 (Arts. 8-35).

38. Id.

39. Ryszard Cholewinski, Migrant Workers in International Human Rights Law: Their Protection in Countries of Employment 191 (1997).

40. Id. at 192. 
South Korea, and less than minimum wage compensation in Thailand-are prohibited by the terms of the Convention. The Convention is the first U.N. instrument to address specifically the rights of the undocumented, the most marginal and invisible subsections of the population worldwide. Further, the Convention also explicitly recognizes that the best method of limiting clandestine immigration is to attack the problem at its root-employers' demand for exploitable labor. The Convention presupposes that the employers' hiring of workers in contravention of immigration laws, not the workers' presence, is the unlawful act. ${ }^{41}$

However, despite the step taken by recognizing the rights of the undocumented, on a practical level the Migrant Workers Convention and the human rights framework in general have little to offer individuals who are living and working outside of their home country without documentation. ${ }^{42}$ There are several practical problems with the obligations imposed by the Convention. Most importantly, the Convention has not been ratified by any key receiving countries. As demonstrated by the strong ratification and accession records of the ICCPR and the ICESCR, most countries are willing to make at least a symbolic commitment to human rights by signing and ratifying treaties. The record on the Migrant Workers Convention, however, shows exactly the opposite. The Convention was adopted in 1991 as a resolution by the General Assembly, with an article providing that it would not enter into force as a treaty until it received at least twenty ratifications. ${ }^{43}$ It was not until 2003 that the Migrant Workers Convention received the twenty ratifications necessary to become binding international law. Of course, it can be expected that treaties affording rights to undocumented residents of a country will prove more challenging than other human rights treaties, as clandestine immigration directly implicates issues of a state's territorial sovereignty. ${ }^{44}$ However, the Migrant Workers Convention has a particularly dismal ratification record as compared to other human rights treaties. To date, the Convention has not been signed or ratified by any EU Member States, Canada, the United States, or any immigrant-receiving countries in Asia or the Middle East. As long as most receiving states stay out of the agreement, there is no way to put international political pressure on these countries through the United Nations or through the human rights framework.

Second, even if many migrant-receiving countries did choose to ratify the Migrant Workers Convention, there are other significant barriers to exercising the

41. See id. at 147.

42. See Stevens, supra note 21 , at 416-18.

43. Migrant Workers Convention, supra note 36, at Art. 87, If 1.

44. See Stevens, supra note 21, at 406. 
rights enumerated in the Convention. Although the Convention has optional protocols for state complaints and individual complaints as enforcement mechanisms, the only enforcement mechanism mandated by the treaty itself is state reporting. ${ }^{45}$ As has been demonstrated by other treaties, such as the Convention Against Torture, state reporting is often an unreliable enforcement mechanism. ${ }^{46}$ When dealing with as marginal a population as undocumented residents, positive reports are easy to fabricate, and information to the contrary easy to ignore. Further, even if a state is willing to commit to and carry out obligations to protect the rights of irregular migrants enumerated in the Convention, the authorities in host countries may not even hear about abuses of irregular migrants. One of the best sources of this type of information is often from the victims themselves. However, due to fear of deportation, whether or not from explicit threats by the employer, most irregular migrants are extremely hesitant to report employer abuse to the government. In the United States, a country which has one of the highest populations of irregular migrant workers in the world, human rights advocacy organizations have reported a sharp rise in threats of deportation from employers when faced with exposure of abusive practices toward undocumented migrants. ${ }^{47}$ The $\mathrm{Mi}$ grant Workers Convention does not effectively address this deterrent to reporting. Although the Convention mentions the possibility of legalization, it does not mandate that states implement any sort of legalization program, even a very limited one. Nor does the Convention offer any sort of immunity from immigration laws for victims of even the worst abuse at the hands of their employers. In short, there is little chance that the Convention will be implemented in host countries, and even if it is, it may not provide any meaningful protection. ${ }^{48}$

\section{Domestic Solutions}

Although the international community's first and only attempt to provide comprehensive rights to irregular migrant workers has failed among receiving countries, it is notable that many countries do recognize the problem and have attempted do-

45. Cholewinsk I, supra note 39, at 194.

46. See Oona A. Hathaway, The Promise and Limits of the International Law of Torture, in Foundations of International Law and Politics 228, 229 (Oona A. Hathaway \& Harold Hongju Koh eds., 2005).

47. Cleveland, Lyon \& Smith, supra note 28 , at 870.

48. See Margaret L. Satterthwaite, Crossing Borders, Claiming Rights: Using Human Rights Law to Empower Women Migrant Workers, 8 Yale Hum. RTs. \& Dev. L.J. 1, 62 (2005). See also Hathaway, supra note 46. 
mestic solutions. In Ireland, for example, immigration reformers have been calling for rights to family reunification and a system to regularize the status of undocumented immigrants. ${ }^{49}$ Spain instituted a wide regularization program for undocumented workers in 2001 and again in $2005 . .^{50}$ South Korea has also offered similar programs in an attempt to regularize the status of undocumented Filipino workers. ${ }^{51}$ Legalization programs have also been instituted in the United States, where the courts have held that domestic labor laws such as the Fair Labor Standards Act and the National Labor Relations Act apply to undocumented workers. ${ }^{52}$

However, although domestic solutions have helped in some countries, they hardly provide the tools needed to stop exploitation of undocumented workers. Domestic measures such as legalization and authorization of guest workers are difficult to institute because they have little popular support. Further, when instituted, these programs may help those who have sponsors and thus are able to obtain legal status, but those who are unable to legalize are still without protection. To the extent that domestic labor and employment protections apply to the undocumented, in most countries only limited remedies are allowed to these workers. ${ }^{53}$ Further, many scholars have noted that because immigration is a binational or multinational issue, unilateral measures to control migration and to attempt to protect rights of the undocumented continue to be futile. ${ }^{54}$ Unilateral domestic solutions cannot be relied upon to provide long-term protection of rights, as they are subject to changes in politics, government administration, and popular sentiments or fears of the citizens of a particular state. In short, the lack of both depth and endurance of domestic solutions makes it impossible to rely on these solutions to guarantee rights and protection to undocumented workers.

49. Carol Coulter, Call for Integrated Approach by the Government to Immigration, I ISH TIMEs, Oct. 14, 2003, at 6 .

50. See Crawford, supra note 16 . The Spanish government is currently facing a political and social crisis arguably as a result of the decision to legalize, and such measures may not be used as readily in the future. See sources cited supra notes 5-6.

51. Mayen Jaymalin, Stay of 18,000 Filipinos in Korea May Be Legalized, Philippine Headuine News Online, June 8, 2003, http://www.newsflash.org/2003/05/hl/hl018129.htm.

52. Stevens, supra note 21 , at $435-36$.

53. See Hoffman Plastic Compounds, Inc. v. NLRB, 535 U.S. 137, 137 (1992) (holding that while the National Labor Relations Act applies to undocumented workers, an undocumented worker cannot recover back pay as a remedy for violations of the Act). In Spain, the Organic Law on the Rights and Liberties of Foreigners (LOE), passed ostensibly to guarantee immigrants' rights, explicitly excluded undocumented migrants from most of the enumerated rights. Kirry Calavita, I mmigrants at the Margins: Law, Race, and Exclusion in Southern Europe $27-28$ (2005).

54. Vargas, supra note 8 , at 16-17. 


\section{International Trade Treaties And Institutions As A Solution}

As domestic efforts have often failed both in terms of individual rights and as matters of national policy, immigration policy and protection of migrant workers must involve a concerted effort in the international arena. Recently, the language in which these ideas have been expressed has been that of human rights. However, as previously discussed, these efforts have failed to protect undocumented workers, in large part because of the political sensitivities and power politics surrounding the issue of undocumented immigration. Further, as the world economy continues to change, the prospect of protection for all low-wage workers begins to diminish. In recent year the power of unions in industrialized countries has decreased, leading to increased pressure for deregulation in many developed countries. ${ }^{55}$ This decrease in the power of labor has been especially noteworthy in some important receiving countries, including Spain, whose labor movement is widely recognized as the least powerful in Western Europe. ${ }^{56}$ This has all led to the amplification of tension between economic growth and labor standards, and a stagnation of the rate of ratification of all international labor instruments. ${ }^{57} \mathrm{Of}$ course, decreased protection for all workers is particularly threatening for those who had little meaningful protection from the outset.

Increased international trade and competition, however, are not necessarily inimical to the protection of workers. This is especially true in the case of migrant workers, whose home countries have much to gain through remittances from abroad and strong political and social ties to more prosperous countries. For sending countries, there is much political capital to be used in battling for fair treatment of their workers abroad. The economic advantages that these countries receive from a contingent of workers in wealthier countries means that sending countries also have an interest in assuring their citizens have fair working conditions and wages abroad. Increasing economic interdependence means that send-

55. See Marjorie Griffin Cohen \& Stephen McBride, Introduction to Global Turbulence: Social Activists' and State Responses to Globalization 1-7 (Marjorie Griffin Cohen \& Stephen McBride eds., 2003). For a discussion of the decrease in the influence of unions and the effects on migrant workers, see Ruben J. Garcia, Ghost Workers in an Interconnected World: Going Beyond the Dichotomies of Domestic Immigration and Labor Laws, 36 U. Mich. J.L. Reform 737 (2003).

56. Calavita, supra note 53 , at 26 . As Calavita discusses, Spain is an especially telling example in this context because of the change in economic demographics of the immigrant population beginning in the early 1990s. In the 1980s, approximately two-thirds of all immigrants in Spain were ex-patriots from Western Europe and North America, while by the 1990s, about half of all immigrants in Spain were economic migrants from third world countries. Id. at 27.

57. See id. 
ing countries and organizations that work to protect the rights of undocumented migrant workers have two significant vehicles with which to put pressure on receiving countries to commit seriously to the rights of undocumented workers: bilateral and multilateral free trade agreements, and global international institutions such as the World Trade Organization (WTO).

Using trade agreements as vehicles for international commitment to the rights of foreign workers and to promote the movement of labor between countries is not a new concept. Developed countries have often used trade agreements as a medium to encourage the movement of needed labor into the country. The majority of current agreements, however, have two important characteristics that prevent them from assisting those workers who are most vulnerable to exploitation. First, the trade agreements which involve free movement of labor are put in place only between countries that have similar levels of economic development, and therefore do not have much cross-border migration of unskilled laborers. Although still one of the best examples of free movement of immigrant workers between countries of different levels of economic development, in the European Union many wealthier countries only accept immigrant workers from new, poorer EU members after passing through a post-membership transition period. ${ }^{58}$ On top of this, the Member States of the European Union have failed to agree on a common external policy on key immigration issues. ${ }^{59}$ Similarly, the Southern Cone Common Market (MERCOSUR) has agreed to establish a migration system like that of the European Union, but there are not many significant differences in economic development between the member countries. ${ }^{60}$

Second, when agreements are entered into between receiving and sending countries, they include only limited agreements on migrant labor, usually involving

58. When ten new countries joined the EU in 2004, Britain, Sweden and Ireland were the only members that immediately allowed free access to workers from the new members. When Romania and Bulgaria were slated to join the EU in 2007, Britain and Ireland affirmed that they would not give immediate access to Romanian and Bulgarian workers. Sarah Lyall, Britain to Restrict Workers from Bulgaria and Romania, N.Y. TIMEs, October 25, 2006, at A6.

59. Catherine E. Halliday-Roberts, Building a Common Frontier or Deconstructing National Identity?: An Analysis of the Effort to Centralize Control of Third Country Immigration in the European Union, 9 ILSA J. InT'L \& Comp. L. 501,503 (2003).

60. Stephen H. Legomsky, Immigration and Refugee Law and Policy 33 (Foundation Press 2005). MERCOSUR is a South and Central American economic integration project with the purpose of promoting free trade and fluid movement of goods, people, and currency. Currently, Argentina, Brazil, Paraguay, Uruguay, and Venezuela are full members, and Chile, Bolivia, Peru, Colombia and Ecuador are associate members. http://www.mercosur.int/msweb/principal/ contenido.asp (last visited Mar. 4, 2007). 
only skilled workers. Under the North American Free Trade Agreement (NAFTA), for example, the United States legislature authorized a new visa category for workers coming from Canada and Mexico from the United States. ${ }^{61}$ Although this new visa category has benefited some Mexican workers, the category is limited to workers that are "professionals," with at least a bachelor's degree in one of a list of authorized fields. ${ }^{62}$ The Association of Southeast Asian Nations (ASEAN) has similarly "been moving towards allowing the free movement of skilled workers between its 10 member countries, but it has yet to address the much larger movement of unskilled workers. ${ }^{\text {*3 }}$ An estimated 400,000 Indonesians and 170,000 Filipinos are living and working illegally in Malaysia, nearly all of whom are unskilled workers. ${ }^{64}$

When receiving countries do enter into trade treaties with sending countries as is the case with NAFTA and ASEAN, this is a chance for sending countries to put pressure on receiving countries regarding labor rights, legalization, and increased legal immigration opportunities for unskilled workers that are needed in the labor force. The movement of labor is often a necessary part of the relationship between countries, and it is important to recognize this fact. In South Korea, for example, many undocumented workers are allowed to remain clandestinely in the country because their deportation would mean the collapse of small and medium-sized businesses that depend in large part on the undocumented workforce..$^{65} \mathrm{~A}$ similar situation exists in the United States where failure to negotiate over the rights of immigrants has had other notable consequences. Failure to reach an agreement with Mexico over immigration and legalization while drafting the NAFTA led to an increase in the number of undocumented workers in the United States as well as lost opportunities for the United States regarding petroleum supply. ${ }^{66}$ The same is true of other bilat-

61. 9 U.S. Dep't of State, Foreign Affairs Manual 41.59 n.2 (2005), available at http://foia.state. gov/masterdocs/09FAM/0941059N.PDF. These "TN" visas authorized by NAFTA are also available to Canadians, but are rarely issued simply because most Canadian citizens do not need visas to work in the United States.

62. Id. at n.3.1(b).

63. Shawn Donnan, Taufan Hidayat, Roel Landingin \& Jake Lloyd-Smith, Malaysia Delays Round-up of Illegal Migrant Workers, Fin. Times (London), Feb. 2, 2005, at 7.

64. Id.

65. Migrant Workers Refuse Departure, Korea Times, Feb. 11, 2004.

66. Mexico is the largest supplier of crude oil to the United States in the Western Hemisphere. Mexico Led Canada by a Nose as the Largest Crude Oil Supplier to the U.S. in October, Petroleum Intelligence Weekly, Jan. 3, 2005. Former president of Mexico, Carlos Salinas, stated in an interview with journalist Jorge Ramos regarding the negotiations for NAFTA,

President George Bush said to me: 'Look, President Salinas, promoting a free trade agreement with a developing country is going to be very difficult in Congress. If we add in the 
eral and multilateral trade agreements between receiving and sending countries, especially in the realm of access to natural resources. ${ }^{67}$ In cases such as these, both countries lose opportunities such as access to needed goods or labor or a more open market for their own goods. The international community as a whole loses one of its greatest tools to protect the rights of migrants, especially undocumented migrants. These trade agreements can and should be used as a vehicle for sending countries and human rights organizations to put pressure on receiving countries. A list of labor rights that are available to all workers is set out in the Migrant Workers Convention, and this instrument can be used as a guide for countries entering into trade negotiations. Making it known that the state is committed to stopping exploitation of irregular migrants will make these workers less attractive to employers who will abuse them. Further, sending countries should use access to their market and trade in goods to persuade receiving countries to institute other policies necessary to protect migrant workers, such as legalization, guest worker programs, and protection against deportation for immigrant workers who report violations of their labor rights.

Using the context of trade agreements to recognize and enforce labor rights of undocumented workers, institute status regularization programs, and commit to the free movement of needed workers has advantages over both international human rights agreements and domestic solutions. Discussing this issue in the context of bilateral or multilateral trade agreements puts developed nations that are host to many migrant workers in the spotlight, putting pressure on them individually to agree to enforce the rights of migrant workers and to contemplate more realistic immigration schemes. Unlike United Nations human rights agreements, responsibility to ratify cannot be escaped simply by pointing fingers at other receiving countries that have not ratified. Further, including workers' rights in trade agreements asks an individual nation to make a commitment to fair treatment of all workers and conditions very real benefits (access to labor within the sending country, greater access to the sending country's market, and agreement on needed goods) on promising to

issue of immigration it is going to be impossible.' And then he said to me, 'Let's talk about petroleum.' And I answered him, 'Look, President Bush, promoting a new relationship with the United States is going to be very difficult among the Mexican people and in the Senate. And if we include petroleum, it is going to be impossible.' Well, there was not immigration, nor was there petroleum [in the agreement].

Jorge Ramos, a la Caza Del Lé́n 50 (2001) (translated by author).

67. Luis de Sebastián points to the increased demand for primary resources in the international market, and notes that many of these resources are located in developing countries. It is simply a matter of knowing how to make strategic use of international trade of these resources. Sebastián, supra note 15 , at 10 . 
protect the rights of undocumented migrant workers. Especially in light of the failure of human rights instruments to protect labor rights of irregular migrants, institutionalizing these rights in bilateral or multilateral trade agreements makes the obligations of receiving countries much more difficult to ignore.

In addition to trade treaties between individual countries, sending countries can also use global trade institutions such as the WTO instruments to guarantee rights to their citizens when working abroad regardless of immigration status. Unlike many of the human rights instruments such as the Migrant Workers Convention, the ICCPR and the ICESCR, which use self-reporting as the only obligatory method of enforcement, the WTO has strong and binding dispute resolution machinery ${ }^{68}$ At a time when human rights is one of the most important issues on the international agenda, it is anomalous that states' obligations to guarantee human rights are so poorly policed while obligations to other states in the realm of international trade are strictly enforced. To take advantage of the novel enforcement mechanisms in place at the WTO, sending states who are members should not ignore the essential links between migrant labor and free trade, characterizing violations of labor rights as unfair trade practices. Although the idea of establishing and enforcing labor standards through the GATT and the WTO has been introduced on various occasions, it has always been rejected. ${ }^{69}$ Despite this lack of a formal WTO procedure to sanction countries for permitting violations of labor rights, a concerted effort between sending countries from across the globe could at least send a powerful and tangible message about the importance of workers' rights.

Currently, only about one-quarter of WTO member countries are signatories to the Migrant Workers Convention, with even fewer members having actually ratified the treaty. ${ }^{70}$ Unlike in other dispute resolution processes, however, a complaint at the WTO will move forward unless all members form a consensus against it. ${ }^{71}$ This means that nearly every complaint can be heard, even if there is only one coun-

68. For an explanation of the WTO dispute resolution system, and why the system is novel in international law, see Jeffrey Michael Smith, Three Models of Judicial Institutions in International Organizations: The European Union, the United Nations, and the World Trade Organization, 10 Tulsa J. Comp. \& INT'L L.115 (2002).

69. Daniel S. Ehrenberg, From Intention to Action: An ILO-GATT/WTO Enforcement Regime for International Labor Rights, in Human Rights, Labor Rights, and International Trade 163, 164 (Lance A. Compa \& Steven F. Diamond eds., 1996).

70. For a list of WTO members as of January 11, 2007, see World Trade Organization, Understanding the WTO, http://www.wto.org/english/thewto_e/whatis_e/tif_e/org6_e.htm (last visited Mar. 4, 2007).

71. See Joost Pauwelyn, Enforcement and Countermeasures in the WTO: Rules Are Rules-Toward a More Collective Approach, 94 AM. J. INT'L L. 335, 336 (2000). 
try that believes in the merit of the complaint. Although the WTO has not traditionally been a vehicle for airing concerns that can be framed as human rights issues, the structure of the dispute resolution system makes it ideal to bring into the open concerns that a less powerful sending country has about the treatment of its nationals in a receiving country.

Scholars have recognized the potential that the WTO dispute resolution mechanism has for enforcing international labor rights. ${ }^{72}$ The immigration status of the workers, however, complicates the situation as most countries have not been willing to recognize the rights of these workers, much less enforce them. Despite this, even if the WTO machinery can not be used as a method to initiate sanctions against a state for allowing violations of undocumented workers' rights, it can at least be used as a legitimate platform to make information available to the international community regarding these violations. Especially in the area of the rights of undocumented migrant workers, it is important that individual states and the international community recognize how closely the movement of labor and the treatment of foreign labor is connected with free and fair trade by bringing these concerns to light within the framework of the WTO.

\section{Conclusion}

In many ways, the advent of human rights has come about as a response to globalization and increased trade and competition between countries. In many respects, the globalization of trade has had negative implications for many workers, as noted by the stagnation in ratification rates of labor rights instruments. Protecting the rights of the most marginal members of the workforce, irregular migrants, is especially challenging. As the world becomes smaller, more and more workers, especially unskilled workers, leave their home countries to work abroad. At the same time, cheaper labor becomes an advantage in the world market, and undocumented workers are the easiest to exploit. To recognize and enforce the rights of undocumented workers, as well as to take steps to make legal immigration easier and more beneficial, however, does not necessarily mean conflict with principles of an open market and free trade. International trade and sale of goods is intrinsically tied to the workers that make production and sale possible. International trade agreements and institutions can and should be used in areas where human rights and domestic solutions have failed to guarantee the rights of the most vulnerable workers.

72. For an example of a workable and coherent proposal for structuring a labor rights dispute resolution branch within the WTO dispute resolution framework, see Ehrenberg, supra note 69. 
